\title{
Purification and Characterization of a Thermostable Lipase from Geobacillus thermodenitrificans IBRL-nra
}

\author{
Anuradha Balan, ${ }^{1}$ Darah Ibrahim, ${ }^{1}$ \\ Rashidah Abdul Rahim, ${ }^{2}$ and Fatimah Azzahra Ahmad Rashid ${ }^{2}$ \\ ${ }^{1}$ Industrial Biotechnology Research Laboratory, School of Biological Sciences, Universiti Sains Malaysia, 11800 Pulau Pinang, Malaysia \\ ${ }^{2}$ School of Biological Sciences, Universiti Sains Malaysia, 11800 Pulau Pinang, Malaysia
}

Correspondence should be addressed to Anuradha Balan, tulasi79@yahoo.com

Received 17 August 2012; Revised 11 October 2012; Accepted 11 October 2012

Academic Editor: Jose Miguel Palomo

Copyright ( $) 2012$ Anuradha Balan et al. This is an open access article distributed under the Creative Commons Attribution License, which permits unrestricted use, distribution, and reproduction in any medium, provided the original work is properly cited.

\begin{abstract}
Thermostable lipase from Geobacillus thermodenitrificans IBRL-nra was purified and characterized. The production of thermostable lipase from Geobacillus thermodenitrificans IBRL-nra was carried out in a shake-flask system at $65^{\circ} \mathrm{C}$ in cultivation medium containing; glucose $1.0 \%(\mathrm{w} / \mathrm{v})$; yeast extract $1.25 \%(\mathrm{w} / \mathrm{v}) ; \mathrm{NaCl} 0.45 \%(\mathrm{w} / \mathrm{v})$ olive oil 0.1\% (v/v) with agitation of $200 \mathrm{rpm}$ for 24 hours. The extracted extracellular crude thermostable lipase was purified to homogeneity by using ultrafiltration, Heparinaffinity chromatography, and Sephadex G-100 gel-filtration chromatography by 34 times with a final yield of $9 \%$. The molecular weight of the purified enzyme was estimated to be $30 \mathrm{kDa}$ after SDS-PAGE analysis. The optimal temperature for thermostable lipase was $65^{\circ} \mathrm{C}$ and it retained its initial activity for 3 hours. Thermostable lipase activity was highest at pH 7.0 and stable for 16 hours at this $\mathrm{pH}$ at $65^{\circ} \mathrm{C}$. Thermostable lipase showed elevated activity when pretreated with $\mathrm{BaCl}_{2}, \mathrm{CaCl}_{2}$, and $\mathrm{KCl}$ with $112 \%$, $108 \%$, and 106\%, respectively. Lipase hydrolyzed tripalmitin (C16) and olive oil with optimal activity (100\%) compared to other substrates.
\end{abstract}

\section{Introduction}

Lipases (triacylglycerol acylhydrolases, EC 3.1.1.3) catalyse the hydrolysis of long-chain triglycerides with the formation of diacylglycerol, monoacylglycerol, glycerol, and carboxylate, as well as the reverse reaction of the synthesis of esters formed from fatty acids and glycerols [1], present in diverse organisms including animals, plants, fungi, and bacteria. However, only microbial thermostable lipases are commercially significant for their potential use in industries, such as specialty organic syntheses [2], hydrolysis of fats and oils, modification of fats, flavor enhancement in food processing, and chemical analyses [3]. Microbial lipases also have been immensely used for biotechnological applications in dairy, detergents, and textile industries as well as surfactant and oil-processing industries. In fact they have also been widely used in pharmaceutical industries in the production of enaniometrically pure chemicals, since they have a number of unique characteristics couple with in district substrate specificity [4], stable and active in organic solvents [5], do not require cofactors [6], exhibit a high degree of regioselectivity, and possess a wide range of substrate specificity for the conversion of various unnatural substrates [2].

Lipases withydrolase family. The active site is formed by a catalytic triad of Ser, Asp/Glu and His [7]. Lipases share a consensus sequence of GXSXG, whereby X may be any amino acid residue. Lipase exhibits interfacial activation whereby it acts only on emulsified substrates. The active site of lipase is covered by a lid-like $\alpha$-helical structure. The lid moves away upon binding to a lipid interface, causing the active site of lipase fully accessible, enhancing hydrophobic interaction between the enzyme and lipid surface [7].

The major requirement for commercial lipases is thermal stability which would allow enzymatic reaction to be performed at higher temperatures and would be helpful to increase conversion rates, substrate solubility, and to reduce the contamination of microorganism and the viscosity of the 
reaction medium [1]. This has drawn the interest towards thermophiles in both research and industries.

Thermostable enzymes are usually derived from thermophilic microbial strains which may be expected to produce intrinsically more heat-stable enzymes than their mesophilic counterparts. Thermophiles growing at the temperature range of $60-100^{\circ} \mathrm{C}$ have complete thermal equilibrium with the microenvironments and secretes enzymes that are stable at this temperature to support the physiological processes [8]. At present, thermophilic lipases from Bacillus sp. are widely studied and this is due to its unique protein sequence and uncommon biochemical properties [9]. Thermophilic Bacillus species previously assigned to rRNA group 5 have recently been transferred to a new genus Geobacillus [10-12]. The Geobacillus species form a phenotypically and phylogeneticallycoherent group of thermophilic bacilli with high levels of 16S rRNA sequence similarity (98.599.2\%). This group comprises established species of thermophilicbacilli such as Bacillus stearothermophilus [13], Bacillus thermocatenulatus [3], Bacillus thermoleovorans [14], Bacillus kaustophilus [15], Bacillus thermoglucosidasius, and Bacillus thermodenitrificans [11].

Geobacillus thermodinitrificans IBRL-nra was originally isolated from a hot spring in Labok, Kelantan, Malaysia with the temperature of $45^{\circ} \mathrm{C}-50^{\circ} \mathrm{C}$. Its optimal thermostable lipase production in a 5-L stirred-tank bioreactor was previously reported by Balan et al. 2010 [16]. Therefore, the aim of the present work was to purify and characterize the thermostable lipase produced by this strain.

\section{Materials and Methods}

2.1. Microorganism and Culture Maintenance. The bacterial strain, IBRL-nra, used in this study was isolated from a Malaysian hot spring in Labok, Kelantan and identified by 16S rRNA analysis as Geobacillus thermodenitrificans [17]. It was cultured on nutrient agar and maintained at $65^{\circ} \mathrm{C}$. The strain was subcultured every two weeks to maintain its viability.

2.2. Cultivation of Microorganism. G. thermodenitrificans IBRL-nra was grown in a culture medium consisted of $1.00 \%$ $(\mathrm{w} / \mathrm{v})$ glucose, $1.25 \%(\mathrm{w} / \mathrm{v})$ yeast extract, and $0.45 \%(\mathrm{w} / \mathrm{v})$ $\mathrm{NaCl}$ and the $\mathrm{pH}$ was adjusted to 6.8. After sterilization, $0.10 \%$ of olive oil was added together with the $5.0 \%(\mathrm{v} / \mathrm{v} ; 5 \times$ $10^{6}$ cells $/ \mathrm{mL}$ ) of inoculum which was prepared earlier (the inoculum was prepared by transferring 1-2 colonies of $G$. thermodenitrificans IBRL-nra into $3 \mathrm{~mL}$ of culture medium, incubated at temperature $65^{\circ} \mathrm{C}$ with agitation $200 \mathrm{rpm}$ for 24 hours). The inoculated culture medium was then incubated at temperature $65^{\circ} \mathrm{C}$ with agitation $200 \mathrm{rpm}$ for 24 hours.

The fermentation culture was harvested, filtered and centrifuged at $6000 \mathrm{~g}$ for 15 minutes. The cell-free supernatant was collected and used as the crude enzyme.

2.3. Lipase Assay. Lipase activity was determined by using the modified colorimetry method of Kumar et al., 2005 [18]. Culture filtrate $(1.0 \mathrm{~mL})$ was shaken with $2.5 \mathrm{~mL}$ of olive oil emulsion, $1.48 \mathrm{~mL}$ of $100 \mathrm{mM}$ phosphate buffer ( $\mathrm{pH} 7.0$ ), and $20 \mu \mathrm{L}$ of $20 \mathrm{mM} \mathrm{CaCl}_{2}$ in an orbital shaker at an agitation speed of $200 \mathrm{rpm}$ for 30 minutes at $65^{\circ} \mathrm{C}$. The emulsion was prepared by mixing together $1 \%$ polyvinyl alcohol and olive oil $(3: 1 ; \mathrm{v} / \mathrm{v})$ in a homogenizer. The enzyme reaction in the emulsion system was stopped by adding $6 \mathrm{M} \mathrm{HCl}$ $(1.0 \mathrm{~mL})$ and isooctane $(5.0 \mathrm{~mL})$, followed by mixing using a vortex mixer for $30 \mathrm{~s}$. The upper isooctane layer $(4.0 \mathrm{~mL})$ containing the fatty acid was transferred to a test tube containing copper reagent $(200 \mu \mathrm{L})$ and mixed vigorously. The reagent was prepared by adjusting the solution of $5 \%$ (w/v) copper (II) acetate-1-hydrate to $\mathrm{pH} 6.1$ with pyridine. The absorbance of the upper layer was read at $715 \mathrm{~nm}$. Lipase activity was measured by measuring the amount of free fatty acids released based on a standard curve of free fatty acid (oleic acid). One unit of lipase activity was defined as the amount of enzyme releasing $1 \mu$ mole of fatty acid per minute

$$
\text { Lipase activity }(\mathrm{U} / \mathrm{mL})=\frac{\mu \mathrm{mol} / \mathrm{ml}}{\min } .
$$

2.4. Determination of Protein Content. Protein content of cell-free supernatant was determined according to Lowry method [19], using bovine serum albumin as standard.

2.5. Purification. The collected extracellular crude lipase was purified using a three step procedures: ultrafiltration, followed by affinity chromatography and gel-filtration chromatography. The crude lipase was concentrated using the ultracentrifugal filter (Milipore-Amicon) with membrane pore size of $3000 \mathrm{Da}$ about 30 times.

2.6. Affinity Chromatography. The concentrated enzyme collected from the previous step was loaded on a HiTrap Heparin column $(5.0 \mathrm{~mL}, 1.6 \mathrm{~cm} \times 2.5 \mathrm{~cm})$ equilibrated with $10 \mathrm{mM}$ phosphate buffer ( $\mathrm{pH}$ 7.0). The unbound protein was washed out with low ionic strength buffer $(10 \mathrm{mM}$ phosphate buffer, $\mathrm{pH}$ 7.0) until the protein was undetectable at absorbance $280 \mathrm{~nm}$. Then, the enzyme was eluted with high strength buffer (10 $\mathrm{mM}$ phosphate buffer, $1-2 \mathrm{M} \mathrm{NaCl}$, $\mathrm{pH}$ 7.0) using a step elution method. The flow rate was adjusted to $16 \mathrm{~mL} /$ hour and the fraction volume of $4.0 \mathrm{~mL}$ was collected.

2.7. Gel-Filtration Chromatography. The fraction containing lipase with highest activity from affinity chromatography was loaded on Sephadex G-100 column $(40.0 \mathrm{~cm} \times 1.2 \mathrm{~cm})$ equilibrated with $100 \mathrm{mM}$ phosphate buffer, $\mathrm{pH}$ 7.0. The enzyme was then eluted with the same buffer with a flow rate of $1 \mathrm{~mL} / \mathrm{min}$. Fractions of $4 \mathrm{~mL}$ were collected.

2.8. Determination of Molecular Weight. The molecular mass of the purified lipase was determined by SDS-PAGE as described by Laemmli, 1970 [20] using 12.5\% acrylamide gel. Unstained standard protein range: $\beta$-galactosidase $(116.0 \mathrm{kDa})$, bovine serum albumin $(66.2 \mathrm{kDa})$, ovalbumin $(45.0 \mathrm{kDa})$, lactate dehydrogenase (35.0), Rease Bsp981 $(25.0 \mathrm{kDa})$, and $\beta$-lactoglobulin $(18.4 \mathrm{kDa})$ were used as a 
molecular weight marker. The gel was stained with silver staining method as described by Bollag et al. 1996 [21].

2.9. Effect of Temperature on Enzyme Activity and Stability. For the optimum temperature determination, lipase activity was measured by colorimetric assay at different temperature in the range of $40-90^{\circ} \mathrm{C}$ at $\mathrm{pH} 7.0$ in $100 \mathrm{mM}$ phosphate buffer.

For the thermostability, the purified lipase was incubated at $60,65,70$, and $75^{\circ} \mathrm{C}$ for up to $24 \mathrm{~h}$ in $100 \mathrm{mM}$ phosphate buffer, $\mathrm{pH} 7.0$ and residual activity was measured at intervals of $1 \mathrm{~h}$.

2.10. Effect of $p H$ on Enzyme Activity and Stability. The lipase activity was determined at $65^{\circ} \mathrm{C}$ in a $\mathrm{pH}$ range of $4.5-10.5$ using $100 \mathrm{mM}$ different buffers: acetate buffer for $\mathrm{pH}$ 4.5, 5.0; phosphate buffer for $\mathrm{pH} 5.5,6.0,6.5,7.0$, and 7.5; Tris- $\mathrm{HCl}$ buffer for $\mathrm{pH} 8.0$ and 8.5; glycine- $\mathrm{NaOH}$ buffer $\mathrm{pH}$ 9.0, 9.5, 10.0 , and 10.5 .

For the $\mathrm{pH}$ stability, the purified lipase was incubated at $\mathrm{pH} 6.5,7.0$ and $7.5 \mathrm{in}$ different buffers for $24 \mathrm{~h}$ at $65^{\circ} \mathrm{C}$. Residual activity was measured at intervals of $1 \mathrm{~h}$.

2.11. Effect of Metal Ions on Lipase Activity. The purified lipase was preincubated with each of the selected metal ions at final concentration of $1 \mathrm{mM}$ at $65^{\circ} \mathrm{C}$ for $30 \mathrm{~min}$ prior to lipase assay. The lipase activity of the purified enzyme without metal ions was defined as $100 \%$.

2.12. Substrate Specificity. For substrate specificity, triglycerides (C2-C18) with concentration of $10 \mathrm{mM}$ and natural oils (corn oil, palm oil, soy bean oil, canola oil, and sunflower oil) were used as the substrates. The olive oil emulsion was substituted with the various substrates and lipase assay was carried out at $65^{\circ} \mathrm{C}$ with shaking at $200 \mathrm{rpm}$ for $30 \mathrm{~min}$ using the calorimetric method as described earlier.

\section{Results and Discussion}

3.1. Microorganisms. Geobacillus thermodenitrificans IBRLnra as indicated in the name itself is a heat-loving bacteria which is capable of reducing nitrate to nitrogen. It is a Gram-positive rod which forms flat, lobate and off-white colonies (Figure 1). It can grow at $45-70^{\circ} \mathrm{C}$ at $\mathrm{pH} 6-8$ in $0.30 \% \mathrm{NaCl}$. G. thermodenitrificans IBRL-nra used in this study was previously isolated from a hot spring in Kelantan, Malaysia [17]. Figure 1(a) shows the $24 \mathrm{~h}$ old cells that were grown on nutrient agar slant, whereas Figure 1(b) shows the $24 \mathrm{~h}$ old cells that were grown in the cultivation medium. Both micrographs show typical cells of G. thermodenitrificans IBRL-nra.

3.2. Purification. The extracellular lipase from G. thermodentrificans IBRL-nra was purified using a three step procedures: ultrafiltration, affinity chromatography, and gel filtration chromatography. The highest lipase activity was detected at fraction 18 with $308 \mathrm{U} / \mathrm{mL}$ in affinity chromatography. Affinity chromatography was used in this study to minimize the purification steps and the loss of enzyme [6]. Heparin used is a highly sulphated glucosaminoglycan with a broad affinity for lipase. The partially purified lipase was then chromatographed on Sephadex G-100 gel filtration. A single peak of lipase was detected at fraction 17 with $92.2 \mathrm{U} / \mathrm{mL}$ activity. SDS-PAGE analysis of lipase exhibited a singleband with molecular mass estimated to be $30 \mathrm{kDa}$ (Figure 2). Lipases from Bacillus are reported to have low molecular weight of $\sim 20 \mathrm{kDa}$ [22]. Lipases with lower molecular weight have advantage as smaller enzymes are more stable due to smaller changes (unfolding) in tertiary structure [23]. The purification summary is tabulated in Table 1. After a three step purification procedures, crude lipase was purified to homogeneity by 34 fold from the culture supernatant with specific activity of $36.7 \mathrm{U}$ and a final recovery of 9\%. Sifour et al. 2010 [24] reported that a thermostable lipase was purified from Geobacillus stearothermophilus using ultrafiltration, Q-Sepharose ion exchange chromatography, Sephadex G-100 gel filtration, and adsorption on hydroxyl apatite to 22.6 fold with $8.8 \%$ recovery and molecular weight of $61 \mathrm{kDa}$. Smaller lipases have been reported by Chartrain et al. 1993 [25] (29 kDa), Kohno et al. 1994 [26] (30 kDa), Ohnishi et al. 1994b [27] (24 kDa), Mase et al. 1995 [28] $(24 \mathrm{kDa})$, Lee et al. $1999(35 \mathrm{kDa})$ [29], and Sharma et al. 2002 [30] (37 kDa). Kumar et al., 2005 [18], reported that an alkaline thermostable lipase was purified from $B$. coagulans BTS-3 with molecular weight of $31 \mathrm{kDa}$. In contrast, thermotolerant metallolipase from B. coagulans MTCC- 6375 was reported to be $103 \mathrm{kDa}$ in size [31]. However, there are also relatively higher $\mathrm{Mr}$ lipase that have been reported from B. stearothermophilus [13], B. thermocatenulatus BTL2 [32], Bacillus sp. 398 [33], and Bacillus sp. J33 [34] possessing $\mathrm{Mr}$ of $62.5 \mathrm{kDa}, 69 \mathrm{kDa}, 50 \mathrm{kDa}$, and $60 \mathrm{kDa}$, respectively.

The final yield of thermostable lipase is quite low, however this study is only to characterize the enzyme for its good properties. The enzyme yield may be enhanced by immobilization or cloning and expression of the lipase gene. Immobilization of lipase enhances its stability and activity and improves recyclability of the enzyme [6]. Palomo et al. 2004 [35] reported that lipase activity of Bacillus thermocatenulatus (BTL2) immobilized with hydrophobic resin (octadecly-Sepabeads) was increased and retained $100 \%$ of its initial activity after incubation for $50 \mathrm{~h}$ at $65^{\circ} \mathrm{C}$.

3.3. Effect of Temperature. Figure 3 shows the effect of temperature on lipase activity. It was detected in temperature range of $40-90^{\circ} \mathrm{C}$ (Figure $3(\mathrm{a})$ ) at $\mathrm{pH}$ 7.0. The optimum temperature of purified lipase was $65^{\circ} \mathrm{C}$, followed by 60 and $70^{\circ} \mathrm{C}$. The activity dropped sharply above $75^{\circ} \mathrm{C}$ with only $20 \%$ of activity left at $80^{\circ} \mathrm{C}$. Four temperatures $(60,65$, 70 , and $75^{\circ} \mathrm{C}$ ) with highest activity were then chosen for thermostability study. There was no loss of activity for the first 60 minutes at 65 and $70^{\circ} \mathrm{C}$ (Figure 3(b)) and the activity dropped slightly thereafter. However, around $90 \%$ of the original activity was retained for $3 \mathrm{~h}$ and $2 \mathrm{~h}$ at 65 and $70^{\circ} \mathrm{C}$, respectively. The result obtained shows that the thermostable lipase of G. thermodenitrificans IBRL-nra is highly stable compared to lipase from Geobacillus stearothermophilus [24] 


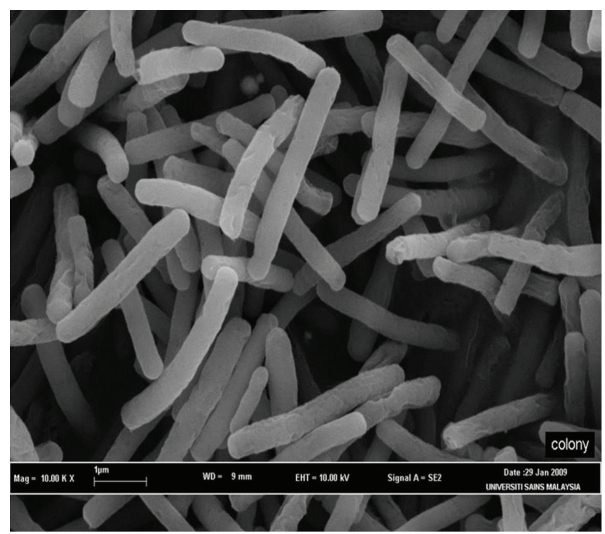

(a)

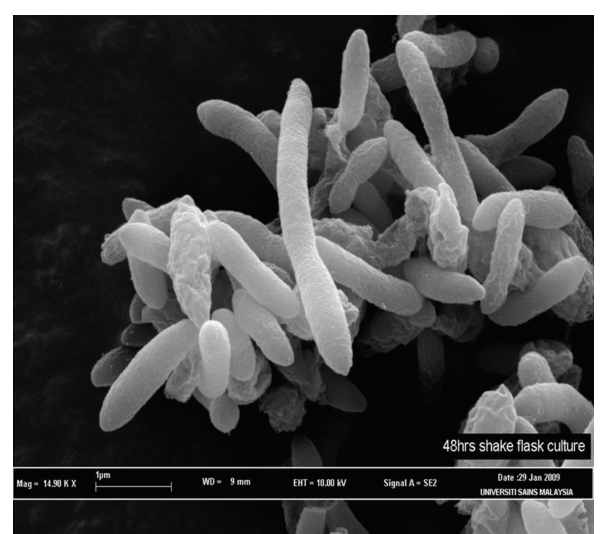

(b)

FIGURE 1: SEM micrograph of G. thermodenitrificans IBRL-nra. (a) $24 \mathrm{~h}$ old cells that were grown on nutrient agar slant, (b) the $24 \mathrm{~h}$ old cells that were grown in a cultivation medium in a shake flasks system.

TABLe 1: Summary of purification of thermostable lipase from G. thermodentrificans.

\begin{tabular}{|c|c|c|c|c|c|}
\hline Purification step fold & Total activity (U) & Total Protein $(\mathrm{mg})$ & Specific activity (U/mg) & Yield (\%) & Fold \\
\hline Crude lipase & 4167.0 & 3840.0 & 1.09 & 100.0 & 1 \\
\hline Ultrafiltration & 3088.82 & 942.28 & 3.28 & 74.1 & 3.0 \\
\hline Affinity Chromatography & 1232.0 & 144.32 & 8.54 & 29.6 & 7.8 \\
\hline Gel-filtration & 368.88 & 10.05 & 36.7 & 8.9 & 33.7 \\
\hline
\end{tabular}

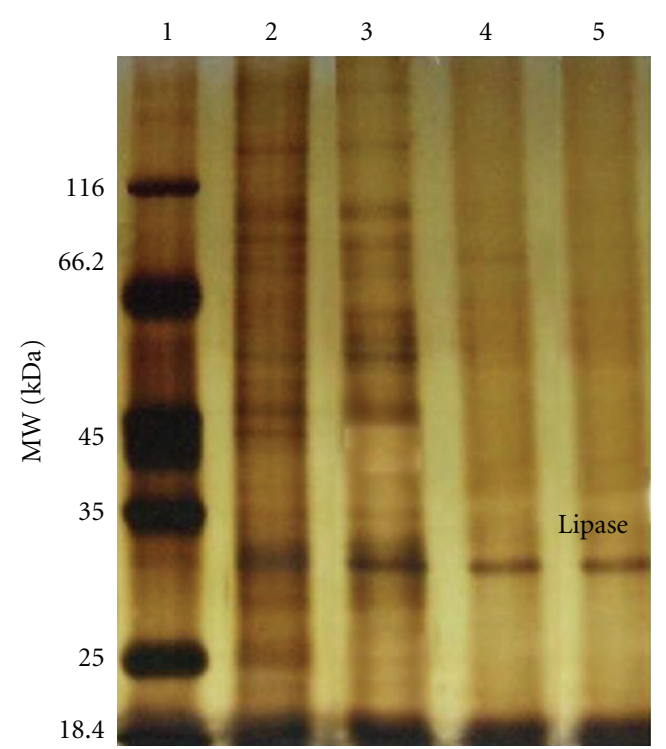

Figure 2: SDS-PAGE (12.5\%) of thermostable lipase from G. thermodenitrificans IBRL-nra. Lane 1: unstained protein molecular weigth marker are $\beta$-galactosidase $(116.0 \mathrm{kDa})$, bovine serum albumin $(66.2 \mathrm{kDa})$, ovalbumin $(45.0 \mathrm{kDa})$, lactate dehydrogenase $(35.0 \mathrm{kDa})$, Rease Bsp981 $(25.0 \mathrm{kDa})$, and $\beta$-lactoglobulin $(18.4 \mathrm{kDa})$. Lane 2 : crude lipase. Lane 3: concentrated lipase. Lane 4: partially purified lipase. Lane 5: purified lipase.

with only $87.5 \%$ of its original activity retained after 15 minutes of exposure at $70^{\circ} \mathrm{C}$. The half life of the purified lipase was $8 \mathrm{~h}$ at $60^{\circ} \mathrm{C}, 16 \mathrm{~h}$ at 65,70 , and $75^{\circ} \mathrm{C}$, respectively
(Figure 3(b)). Sharma et al. 2002 [30] reported that the lipase from Bacillus sp. RSJ-1 had optimum activity at $50^{\circ} \mathrm{C}$ and it retained 96, 92, 78 and $34 \%$ of its maximum activity and half-life of 150, 90, 55, and 45 minutes at 55, 60, 65, and $70^{\circ} \mathrm{C}$, respectively. Another highly thermostable lipase was isolated by Wang et al., 1995 [36] from Bacillus strain and the half life of the enzyme was 8 hour at $75^{\circ} \mathrm{C}$ and it retained at least $90 \%$ of the original activity for 15 hour at $60^{\circ} \mathrm{C}$. The characteristics of the lipase from $G$. thermodenitrificans IBRL-nra make it belongs to the thermostable enzyme because it showed an optimal activity at $65^{\circ} \mathrm{C}$.

3.4. Effect of $p H$. Changes in $\mathrm{pH}$ will affect the protein structure and the enzyme activity [27]. The effect of $\mathrm{pH}$ on lipase activity is shown in Figure 4, where lipase showed activity in the $\mathrm{pH}$ range of 6.0-8.0 (Figure 4(a)). Maximal activity was observed at $\mathrm{pH} 7.0$ followed by 6.5 and 7.5 (phosphate buffer) and the activity dropped at $\mathrm{pH} 8.0$ onwards. No loss of activity over $16 \mathrm{~h}$ was observed when the lipase was preincubated at $\mathrm{pH} 7.0$ and 7.5 (Figure 4(b)). $100 \%$ of activity was retained for $8 \mathrm{~h}$ at $\mathrm{pH} 6.5$. However lipase retained $85 \%, 90 \%$, and $80 \%$ of its original activity for $24 \mathrm{~h}$ at $\mathrm{pH} 6.5,7.0$, and 7.5, respectively. Purified lipase from Geobacillus stearothermophilus, retained 95-100\% of its original activity for 30 minutes at $60^{\circ} \mathrm{C}$ after incubation at pH 5-9 [21]. Kumar et al., 2005 [18] reported that the purified lipase from $B$. coagulans BTS-3 was stable within a $\mathrm{pH}$ range of 8.0-10.5 with optimum activity at $\mathrm{pH}$ 8.5. Lipase from B. stearothermophilus MC7 had pH optimum within the 


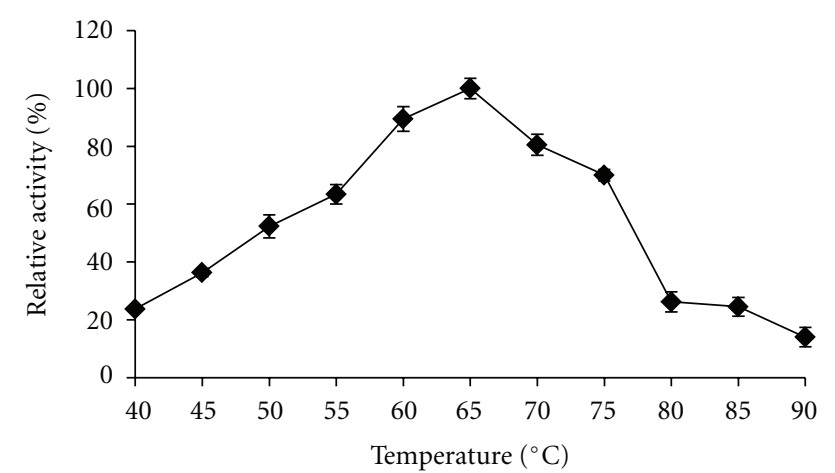

(a)

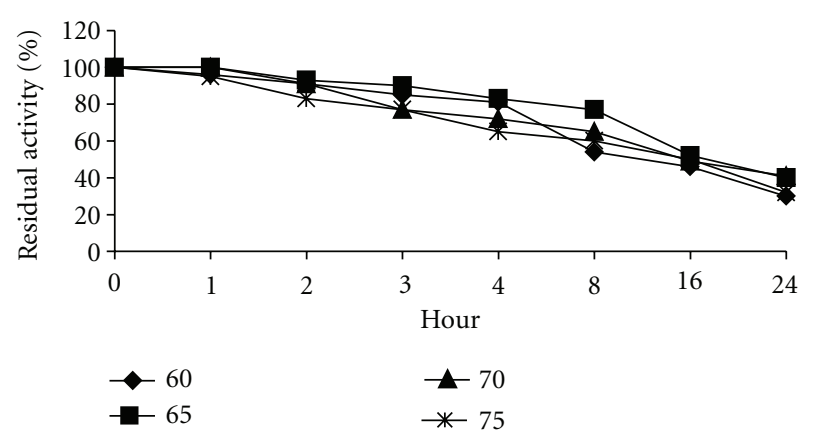

(b)

FIGURE 3: Effect of temperature on thermostable lipase activity. The lipase activity at $65^{\circ} \mathrm{C}(130.56 \mathrm{U} / \mathrm{mL})$ was set as $100 \%$ (a). Thermostability of the purified lipase. The activity of lipase without preincubation $(95.0 \mathrm{U} / \mathrm{mL})$ was set as $100 \%$ (b).

range of 7.5-9.0 and was stable at alkaline $\mathrm{pH}$ range 7.0-11.0 at $60^{\circ} \mathrm{C}$ [22]. Study on lipase from Bacillus sp. RSJ- 1 showed a maximum activity at $\mathrm{pH} 8.0(100 \%)$ and followed by $\mathrm{pH} 9.0$ (99\%) and it retained $84 \%$ and $82 \%$ of its maximum activity at $\mathrm{pH} 8$ and 9 , respectively, for 2 hours at $50^{\circ} \mathrm{C}[30]$.

3.5. Effect of Metal Ions on Lipase Activity. Metal ions are reported to stimulate lipase-catalyzed hydrolysis of oil by removing the fatty acids from the oil-water interface and allowing lipase to act freely on oil molecules [23]. Thermostable lipase activity was enhanced by several metal ions $(1 \mathrm{mM})$ with highest relative activity achieved when the enzyme was pretreated with $\mathrm{BaCl}_{2}, \mathrm{CaCl}_{2}$, and $\mathrm{KCl}$ with $112 \%, 108 \%$, and 106\%, respectively (Figure 5). Kambourova et al. 2003 [13] suggested that the positive effect of $\mathrm{Ca}^{2+}$ is due to formation of insoluble ion-salts of fatty acids during hydrolysis, thus avoiding the product inhibition. Rahman et al. 2005 [37] stated that metal ions will bind to the enzyme and change the enzyme's conformation to counter better stability and hence greater activity.

However the enzyme activity was slightly inhibited to $78 \%$ when preincubated with $\mathrm{MoO}_{3}$. In a previous study, the thermotolerant lipase from Bacillus sp. RN2 was slightly enhanced by $\mathrm{KCl}, \mathrm{CaCl}_{2}$ and $\mathrm{ZnCl}_{2}$ [34]. Sifour et al., 2010 [24] also found $\mathrm{CaCl}_{2}$ strongly improved the lipase activity

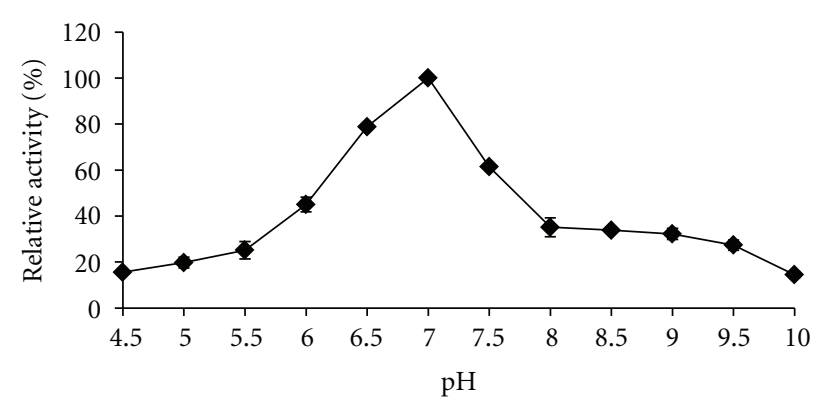

(a)

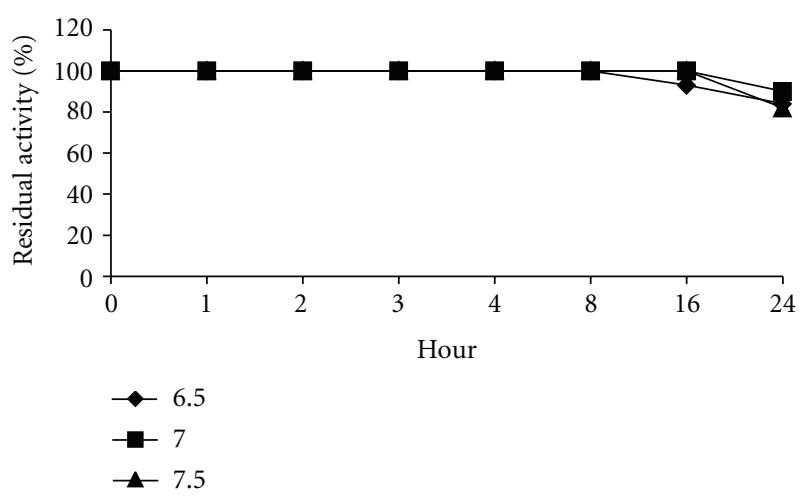

(b)

Figure 4: Effect of $\mathrm{pH}$ on thermostable lipase activity at $65^{\circ} \mathrm{C}$. The lipase activity at $\mathrm{pH} 7.0(102.5 \mathrm{U} / \mathrm{mL})$ was set as $100 \%$ (a). $\mathrm{pH}$ stability of purified thermostable lipase, the activity of thermostable lipase without preincubation $(95.0 \mathrm{U} / \mathrm{mL})$ was set as $100 \%$ (b).

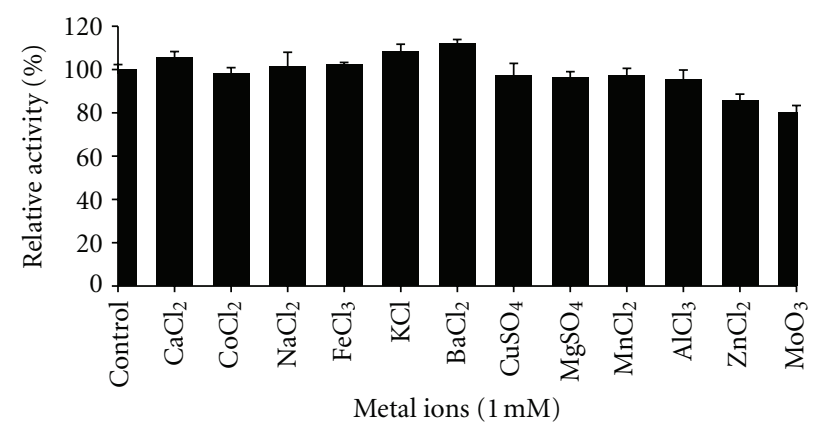

FIGURE 5: Effect of metal ions on thermostable lipase activity. Lipase activity without addition of metal ions, control $(111.7 \mathrm{U} / \mathrm{mL})$ was set as $100 \%$.

from Geobacillus stearothermophilus Strain-5 to 155\%. However the lipase activity was inhibited by $\mathrm{CuSO}_{4}$ and $\mathrm{HgCl}_{2}$.

3.6. Substrate Specificity. Figures 6 and 7 displays the substrates (triglycerides and natural oil) specificity of purified lipase. Lipase activity increased from C8 to C16 and the highest lipase activity was observed at C16 (tripalmitin) with 100\% activity, followed by C18 (tristearin) and C14 (trimystrin) with $60 \%$ activity. The enzyme hydrolyzed triacylglycerols with acyl-group chain lengths between C8 


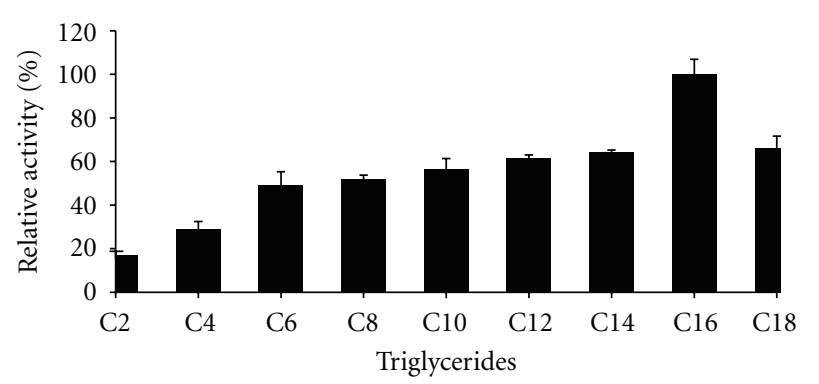

Figure 6: Effect of triglycerides on thermostable lipase activity. Highest lipase activity at C16 (109.18 U/mL) was set as $100 \%$.

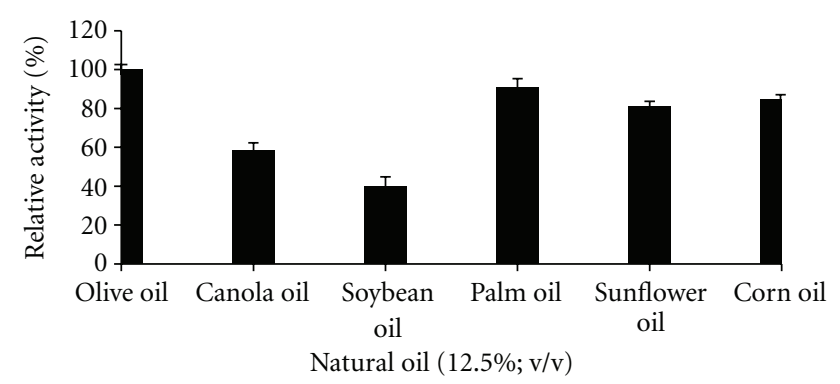

FIgURE 7: Effect of natural oils on thermostable lipase activity. Lipase activity of $122.29 \mathrm{U} / \mathrm{mL}$ using olive oil as the substrate (control) was set as $100 \%$.

and $\mathrm{C} 18$ with better activity compared to short chain acylgroup (C2-C6). The preference of the enzyme towards longchain triacylglycerols indicates that it is a true lipase. Its high affinity towards long-chain triacylglycerols suggests that this enzyme has potential role in the food and diary industry especially in hydrolysis of milk fat, cheese ripening, modification of butter, and flavour development in meat and fish.

In the natural oil study, lipase hydrolyzed olive oil with optimal activity (100\%) followed by palm oil (96\%), corn oil (90\%), and sunflower oil (86\%). The lowest lipase activity was obtained when soybean oil and canola oil were used as the substrate. Lipase from G. stearothermophilus Strain-5 had highest affinity towards tributyrin [38], while thermoalkaliphilic lipase of Geobacillus sp. T1 hydrolyzed sunflower oil rapidly [39]. The ability of this thermostable enzyme in hydrolysis of vegetable oils could be employed in fat and oil industry especially retailoring and upgrading the vegetable oils into nutritionally important products like PUFA and cocoa butter replacer.

Based on the results obtained, the thermostable lipase from G. thermodenitrificans IBRL-nra is a potential candidate for biotechnological application and could be exploited in industries especially in food and dairy, pharmaceutical, nutraceuticals, detergent, fat and oil, and organic synthesis industries. The enzyme also has potential usage in the production of biodiesel from vegetable oils. However the enzyme yield could be further improved via immobillization and cloning to enhance the good properties of this enzyme. The cloning and overexpression of the lipase gene from
G. thermodenitrificans is in progress and the recombinant thermostable lipase will be used for the three-dimensional structure elucidation.

\section{Acknowledgment}

The authors would like to extend their appreciation to Universiti Sains Malaysia for awarding the Fellowship Scheme and Post-Graduate Research Grant Scheme to support this research.

\section{References}

[1] H. Li and X. Zhang, "Characterization of thermostable lipase from thermophilic Geobacillus sp. TW1," Protein Expression and Purification, vol. 42, no. 1, pp. 153-159, 2005.

[2] B. Rubin and E. A. Dennis, "Lipases: part B. Enzyme characterization and utilization," Methods in Enzymology, vol. 286, pp. 1-563, 1997.

[3] I. Kauffmann and C. Schmidt-Dannert, "Conversion of Bacillus thermocatenulatus lipase into an efficient phospholipase with increased activity towards long-chain fatty acyl substrates by directed evolution and rational design," Protein Engineering, vol. 14, no. 11, pp. 919-928, 2001.

[4] V. Nagy, E. R. Toke, L. C. Keong et al., "Kinetic resolutions with novel, highly enantioselective fungal lipases produced by solid state fermentation," Journal of Molecular Catalysis B, vol. 39, no. 1-4, pp. 141-148, 2006.

[5] F. Niehaus, C. Bertoldo, M. Kähler, and G. Antranikian, "Extremophiles as a source of novel enzymes for industrial application," Applied Microbiology and Biotechnology, vol. 51, no. 6, pp. 711-729, 1999.

[6] R. Sharma, Y. Chisti, and U. C. Banerjee, "Production, purification, characterization, and applications of lipases," Biotechnology Advances, vol. 19, no. 8, pp. 627-662, 2001.

[7] K. E. Jaeger and M. T. Reetz, "Microbial lipases form versatile tools for biotechnology," Trends in Biotechnology, vol. 16, no. 9, pp. 396-403, 1998.

[8] D. A. Cowan and R. Fernandez-Lafuente, "Enhancing the functional properties of thermophilic enzymes by chemical modification and immobilization," Enzyme and Microbial Technology, vol. 49, no. 4, pp. 326-346, 2011.

[9] M. I. Massadeh and F. M. Sabra, "Production and characterization of lipase from Bacillus stearothermophilus," African Journal of Biotechnology, vol. 10, no. 61, pp. 13139-13146, 2011.

[10] C. Ash, J. A. E. Farrow, S. Wallbanks, and M. D. Collins, "Phylogenetic heterogeneity of the genus Bacillus revealed by comparative analysis of small-subunit-ribosomal RNA sequences," Letters in Applied Microbiology, vol. 13, no. 4, pp. 202-206, 1991.

[11] T. N. Nazina, T. P. Tourova, A. B. Poltaraus et al., "Taxonomic study of aerobic thermophilic bacilli: descriptions of Geobacillus subterraneus gen. nov., sp. nov. and Geobacillus uzenensis sp. nov. from petroleum reservoirs and transfer of Bacillus stearothermophilus, Bacillus thermocatenulatus, Bacillus thermoleovorans, Bacillus kaustophilus, Bacillus thermoglucosidasius and Bacillus thermodenitrificans to Geobacillus as the new combinations G. stearothermophilus, G. thermocatenulatus, G. thermoleovorans, G. kaustophilus, G. thermoglucosidasius 
and G. thermodenitrificans," International Journal of Systematic and Evolutionary Microbiology, vol. 51, no. 2, pp. 433-446, 2001.

[12] F. A. Rainey, D. Fritze, and E. Stackebrandt, "The phylogenetic diversity of thermophilic members of the genus Bacillus as revealed by $16 \mathrm{~S}$ rDNA analysis," FEMS Microbiology Letters, vol. 115, no. 2-3, pp. 205-211, 1994.

[13] M. Kambourova, N. Kirilova, R. Mandeva, and A. Derekova, "Purification and properties of thermostable lipase from a thermophilic Bacillus stearothermophilus MC 7," Journal of Molecular Catalysis B, vol. 22, no. 5-6, pp. 307-313, 2003.

[14] D. W. Lee, Y. S. Koh, K. J. Kim et al., "Isolation and characterization of a thermophilic lipase from Bacillus thermoleovorans ID-1," FEMS Microbiology Letters, vol. 179, no. 2, pp. 393-400, 1999.

[15] L. L. Lin, W. H. Hsu, C. P. Wu, M. C. Chi, W. M. Chou, and H. Y. Hu, "A thermostable leucine aminopeptidase from Bacillus kaustophilus CCRC 11223," Extremophiles, vol. 8, no. 1, pp. 7987, 2004.

[16] A. Balan, N. Magalinggam, D. Ibrahim, and R. A. Rahim, "Thermostable lipase production by Geobacillus thermodenitrificans in a 5-L stirred-tank bioreactor," Internet Journal of Microbiology, vol. 8, no. 2, 9 pages, 2010.

[17] N. N. H. Raikhan, Penghasilan Enzim Lipase Termotoleran daripada Aktinomiset Streptosporangium roseum [M.S. thesis], Universiti Sains Malaysia, Penang, Malaysia, 2003.

[18] S. Kumar, K. Kikon, A. Upadhyay, S. S. Kanwar, and R. Gupta, "Production, purification, and characterization of lipase from thermophilic and alkaliphilic Bacillus coagulans BTS-3," Protein Expression and Purification, vol. 41, no. 1, pp. 38-44, 2005.

[19] O. H. Lowry, A. Rosebrough, L. Farr, and R. J. Randall, "Protein measurement with the Folin phenol reagent," The Journal of Biological Chemistry, vol. 193, no. 1, pp. 265-275, 1951.

[20] U. K. Laemmli, "Most commonly used discontinuous buffer system for SDS electrophoresis," Nature, vol. 227, pp. 680-686, 1970.

[21] D. M. Bollag, M. D. Rozycki, and S. J. Edelstein, Protein Methods, Wiley-Liss, New York, NY, USA, 1996.

[22] A. Sugihara, T. Tani, and Y. Tominaga, "Purification and characterization of a novel thermostable lipase from Bacillus sp." Journal of Biochemistry, vol. 109, no. 2, pp. 211-216, 1991.

[23] C. Sharon, M. Nakazato, H. I. Ogawa, and Y. Kato, "Lipaseinduced hydrolysis of castor oil: effect of various metals," Journal of Industrial Microbiology and Biotechnology, vol. 21, no. 6, pp. 292-295, 1998.

[24] M. Sifour, H. M. Saeed, T. I. Zaghloul, M. M. Berekaa, and Y. R. Abdel-Fattah, "Purification and properties of a lipase from thermophilic Geobadllus stearothermophilus strain-5," International Journal of Biological Chemistry, vol. 4, no. 4, pp. 203-212, 2010.

[25] M. Chartrain, L. Katz, C. Marcin et al., "Purification and characterization of a novel bioconverting lipase from Pseudomonas aeruginosa MB 5001," Enzyme and Microbial Technology, vol. 15, no. 7, pp. 575-580, 1993.

[26] M. Kohno, W. Kugimiya, Y. Hashimoto, and Y. Morita, "Purification, characterization, and crystallization of two types of lipase from Rhizopus niveus," Bioscience, Biotechnology and Biochemistry, vol. 58, no. 6, pp. 1007-1012, 1994.
[27] K. Ohnishi, Y. Yoshida, J. Toita, and J. Sekiguchi, "Purification and characterization of a novel lipolytic enzyme from Aspergillus oryzae," Journal of Fermentation and Bioengineering, vol. 78, no. 6, pp. 413-419, 1994.

[28] T. Mase, Y. Matsumiya, and T. Akiba, "Purification and characterization of a new lipase from Fusarium sp. YM-30," Bioscience, Biotechnology, and Biochemistry, vol. 59, no. 9, pp. 1771-1772, 1995.

[29] D. W. Lee, Y. S. Koh, K. J. Kim et al., "Isolation and characterization of a thermophiliclipase from Bacillus thermoleovorans ID-1," FEMS Microbiology Letters, vol. 179, no. 2, pp. 393-400, 1999.

[30] R. Sharma, S. K. Soni, R. M. Vohra, L. K. Gupta, and J. K. Gupta, "Purification and characterisation of a thermostable alkaline lipase from a new thermophilic Bacillus sp. RSJ-1," Process Biochemistry, vol. 37, no. 10, pp. 1075-1084, 2002.

[31] S. S. Kanwar, I. A. Ghazi, S. S. Chimni et al., "Purification and properties of a novel extra-cellular thermotolerant metallolipase of Bacillus coagulans MTCC-6375 isolate," Protein Expression and Purification, vol. 46, no. 2, pp. 421-428, 2006.

[32] C. Schmidt-Dannert, M. L. Rúa, and R. D. Schmid, "Two novel lipases from thermophile Bacillus thermocatenulatus: screening, purification, cloning, overexpression, and properties," Methods in Enzymology, vol. 284, pp. 194-220, 1997.

[33] H. K. Kim, S. Y. Park, J. K. Lee, and T. K. Oh, "Gene cloning and characterization of thermostable lipase from Bacillus stearothermophilus L1," Bioscience, Biotechnology and Biochemistry, vol. 62, no. 1, pp. 66-71, 1998.

[34] N. Nawani and J. Kaur, "Purification, characterization and thermostability of lipase from a thermophilic Bacillus sp. J33," Molecular and Cellular Biochemistry, vol. 206, no. 1-2, pp. 9196, 2000.

[35] J. M. Palomo, R. L. Segura, G. Fernández-Lorente et al., "Purification, immobilization, and stabilization of a lipase from Bacillus thermocatenulatus by interfacial adsorption on hydrophobic supports," Biotechnology Progress, vol. 20, no. 2, pp. 630-635, 2004.

[36] Y. Wang, K. C. Srivastava, G. J. Shen, and H. Y. Wang, "Thermostable alkaline lipase from a newly isolated thermophilic Bacillus, strain A30-1 (ATCC 53841)," Journal of Fermentation and Bioengineering, vol. 79, no. 5, pp. 433-438, 1995.

[37] R. N. Z. R. A. Rahman, S. N. Baharum, M. Basri, and A. B. Salleh, "High-yield purification of an organic solventtolerant lipase from Pseudomonas sp. strain S5," Analytical Biochemistry, vol. 341, no. 2, pp. 267-274, 2005.

[38] N. S. Abdul Hamid, H. B. Zen, O. B. Tein, Y. M. Halifah, N. Saari, and F. Abu Bakar, "Screening and identification of extracellular lipase-producing thermophilic bacteria from a Malaysian hot spring," World Journal of Microbiology and Biotechnology, vol. 19, no. 9, pp. 961-968, 2003.

[39] T. C. Leow, R. N. Z. R. A. Rahman, M. Basri, and A. B. Salleh, "A thermoalkaliphilic lipase of Geobacillus sp. T1," Extremophiles, vol. 11, no. 3, pp. 527-535, 2007. 

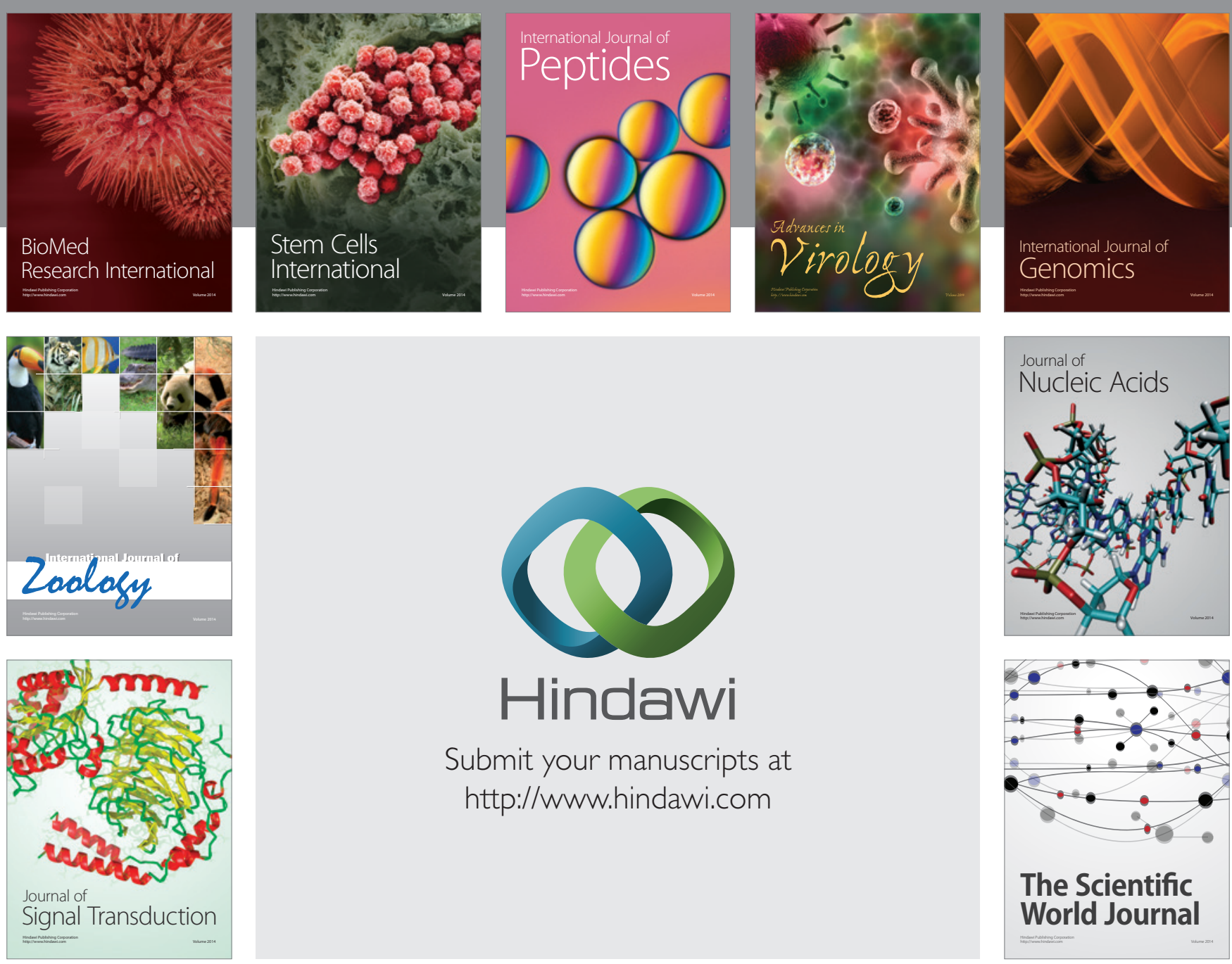

Submit your manuscripts at

http://www.hindawi.com
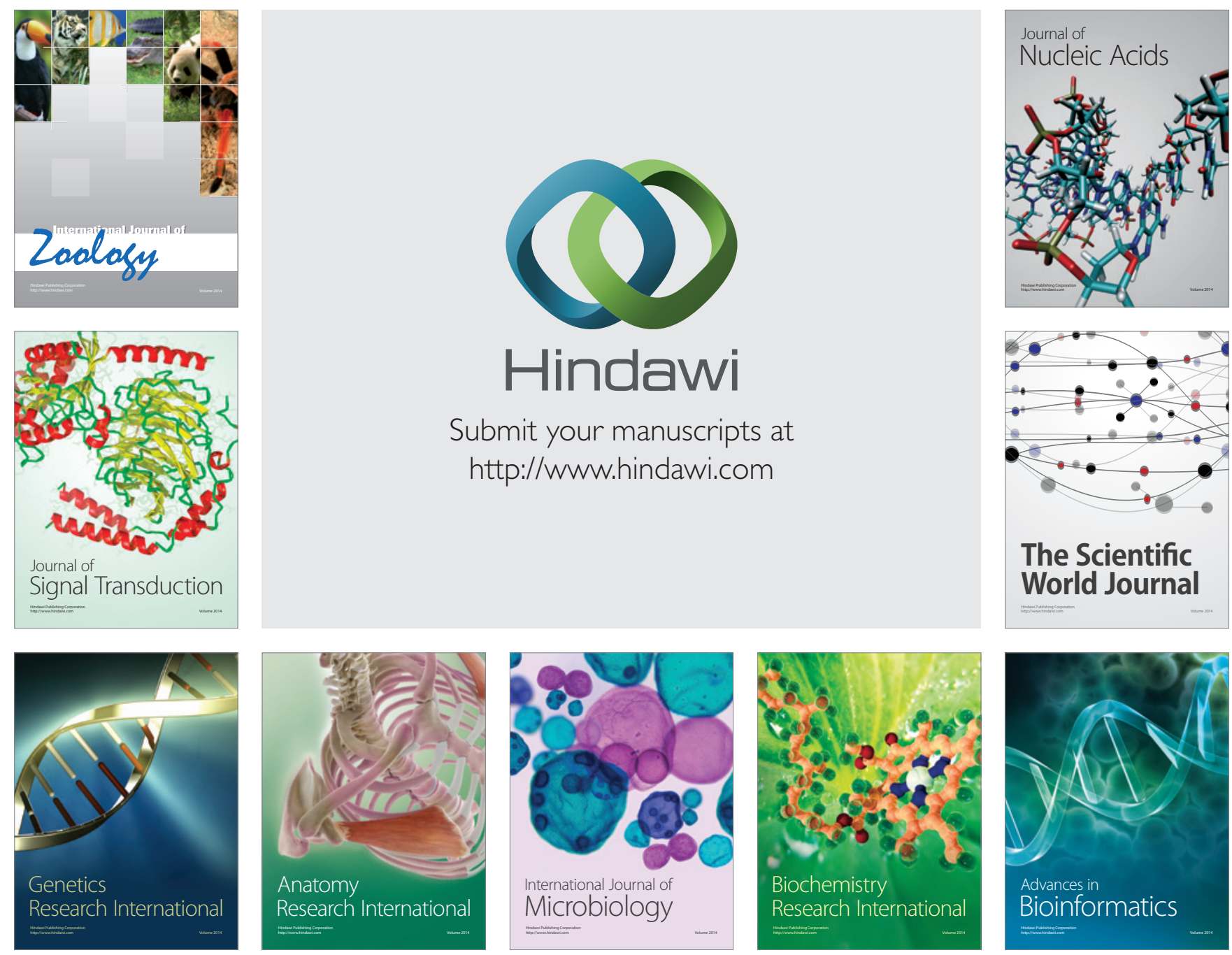

The Scientific World Journal
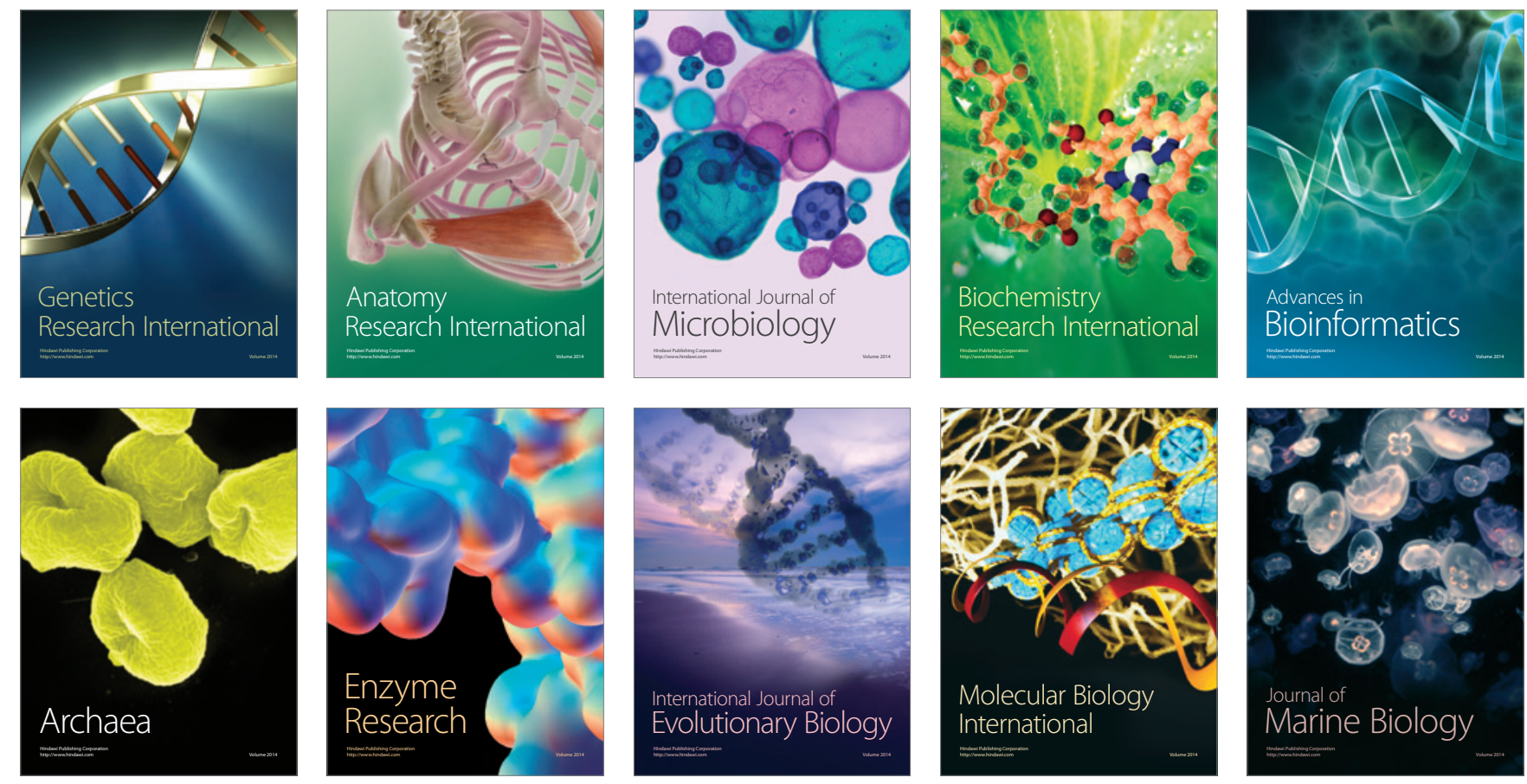